\title{
The Complete Conference Contracted to Manage Spring Meeting Arrangements
}

The Complete Conference, a Sacramento, California based meetings management company, has been contracted by the Materials Research Society to ensure that both the upcoming Spring Meeting in San Francisco and the Fall Meeting in Boston are run as efficiently and effortlessly as possible. President Marilyn Hauck and associate, Merry Geil, are currently working with Spring Meeting Program Chairs A. Wayne Johnson, Susan M. Kelso, and K. A. SreeHarsha to finalize arrangements for this major MRS event.

Marilyn Hauck, with a background in group process and organizational development, coordinates and manages meetings and events of all sizes internationally. She has served on the board of directors for the Northern California chapter of Meeting Planners International for $4 \frac{1}{2}$ years. She has been active in the formation of a new Sacramento chapter of the organization and currently serves as president of the new chapter. She is also involved in the Sacramento Society of Association Executives, is a frequent speaker at industry meetings, and has been nominated for the Sacramento Chamber of Commerce Businesswoman of the Year in a non-traditional role.
Building on her experience with hotel negotiations and meeting management, Hauck has recently expanded the scope of her business to include hotel consultation in the areas of design, marketing, sales and operations, and is presently the project director for the development of a major new hotel in Sacramento

Merry Geil, who joined The Complete Conference a year and a half ago, brought to the company her experience in the management and coordination of local political campaigns and a variety of community projects. She has expertise in the field of aging with emphasis in the area of health care services. She is a charter member of the Sacramento Chapter of Meeting Planners International and is currently serving on the program committee

Both Hauck and Geil view the Materials Research Society as a unique and dynamic organization. They have enjoyed integrating their skills and expertise into the existing planning process and are extremely impressed with the commitment and energy put forth by the Society leadership.

"The Spring Meeting program and symposia chairs have been working for months to make this upcoming meeting in San Francisco the most successful ever," remarked Hauck, "and both Merry and I are looking forward to contributing our part in making sure everything runs smoothly for this important event."

\section{Call for Papers Issued for MRS-Europe Fall Meeting}

Three symposia to address topics in Advanced Materials R\&D for Transport

Light metals, composites, and ceramic coatings for heat engines are the three symposia topics of the 1985 MRS-Europe Fall Meeting being held November 26-29, 1985 Strasbourg, France. Abstracts for both oral and poster presentations are currently being sought in three topics for the conference which will focus on Advanced Materials R\&D for Transport. Contributors should send two copies of one-page abstracts by May 1, 1985 to Centre de Recherches Nucleairs, Laboratoire PHASE, Attention P. Siffert, MRS-Europe 1985 Fall Meeting, 67037 Strasbourg Cedex, France; telephone (88) 286543 .
The meeting is being conducted at the Council of Europe under the auspices of the Council of Europe and the Commission of the European Communities. Co-sponsors of the meeting are Société Française de Métallurgie, Association Europeénne des Matériaux Composites, The Metals Society, Danish Metallurgical Society, Deutsche Gesellschaft für Metallkunde; Deutsche Keramische Gesellschaft, British Ceramics Society, and Association Belge pour favoriser l'étude des verres at des matériaux céramiques.
MRS

\begin{tabular}{|c|} 
MATERIALS \\
RESEARCH \\
SOCIETY
\end{tabular}

See complete

list of

upcoming

technical

meetings

on page 15. 